Gerardo Meil

\title{
Geographic job mobility and parenthood decisions
}

\section{Räumliche berufsbedingte Mobilität und Familienentwicklung}

\begin{abstract}
:
The aim of this paper is to analyse, differentiated by gender, the effects that high geographical job mobility has on parenthood decisions. In particular, in a first part we will examine whether job mobility fosters childlessness and/or postponement of childbearing and if mobility implies a lower family size. In a second part we will analyse how the specific working conditions of mobile people and their resources for balancing working and private lives affect childlessness and postponement of parenthood. The analysis will be based on a representative survey of people aged 25 to 54, performed in six European countries (Germany, France, Spain, Poland, Switzerland and Belgium) in 2007, oversampling mobile people in order to get enough cases to analyse. Results show that the impact of high job mobility on the timing and quantum of parenthood is important, both for men and women, but stronger for the latter. Besides gender, the strength of the impact depends on the duration of job mobility and when it takes place in the lifecycle. Resources for promoting a better balance of working and private lives such as flexitime and teleworking have no clear impact on parenthood decisions, but having a supportive employer facilitates family development of mobile employees. A greater involvement of men in unpaid work does not seem to facilitate fertility decisions of mobile women.
\end{abstract}

\section{Zusammenfassung:}

In diesem Beitrag wird der Frage nachgegangen, inwieweit hohe berufsbedingte räumliche Mobilität negative Folgen auf die Familienentwicklung hat. Im ersten Teil des Aufsatzes wird getrennt nach Geschlecht analysiert, ob Mobilität Kinderlosigkeit fördert, eine Verschiebung des Geburtenkalenders verursacht und ob sie eine Reduktion der Familiengröße zur Folge hat. Darüber hinaus wird in dem zweiten Teil analysiert, welchen Einfluss bestimmte Arbeitsbedingungen sowie die Ressourcen, die Familien zur Verfügung stehen, um Familie und Beruf zu vereinbaren, auf die Entscheidungen bezüglich Elternschaft ausüben. Die Analyse stützt sich auf eine repräsentative Umfrage in sechs europäischen Ländern (Deutschland, Frankreich, Spanien, Polen, Schweiz und Belgien) mit Personen im Alter zwischen 25 und 54 Jahren. Die Daten wurden in 2007 erhoben. Mobile Erwerbstätige wurden überproportional erhoben, um eine ausreichende Fallzahl zu gewährleisten. Die Ergebnisse zeigen, dass die Auswirkung der Mobilität auf die Familienentwicklung von Bedeutung ist, wobei sich Mobilität von Frauen stärker auswirkt. Darüber hinaus ist von Bedeutung, wann im Lebenslauf Mobilität und Elternschaft stattfinden und wie lange die Phase der mobilen Arbeit andauert. Flexible Arbeitszeiten oder die Möglichkeit, einen Teil der Arbeit zu Hause zu leisten, haben keinen eindeutigen Einfluss auf die Entscheidungen zur Elternschaft von mobilen Erwerbstätigen, wohl aber die Unterstützung durch den Arbeitgeber. Unterstüt- 
zung seitens des Partners scheint die Entscheidung mobiler Frauen für Kinder nicht zu fördern.

Key words: job mobility, spatial mobility, fertility, parenthood, balancing working and family lives
Schlagwörter: berufliche Mobilität, räumliche Mobilität, Fertilität, Elternschaft, Vereinbarkeit von Familie und Beruf

\section{Introduction}

In recent decades, fertility rates have been decreasing in almost all industrialised countries, reaching values well below the replacement level. The first approach to explain the causes of very low and lowest-low fertility in these countries is the so-called Second Demographic Transition Theory (Lesthaeghe 1983; Van de Kaa 1987), which relates fertility decisions with the increasing individualisation of industrialised societies. According to this theory, individuals have been gaining ever more freedom to decide on life domains that were traditionally subject to tight social norms. Together with other social changes that make family arrangements less important for the material well-being of men and women, this phenomenon has led to a drastic drop in fertility. The main forces behind the fertility decline would be ideational factors, such as changing values and attitudes and increased female autonomy and independence. Later approaches, assuming that fertility decisions were made less determined by social norms and more dependent on the subjective evaluation of personal circumstances and aspirations, that is in a context of family planning, have stressed more structural factors, such as educational investments and labour market circumstances (among others, Blossfeld/Huinink 1991; Billari/Philipov 2004; Baizan/Martin García 2007). Special attention has been given to analysing the changing relationship between women's employment and fertility at a macro level. While, in the sixties and seventies, this relationship was negative in the OECD area, it became positive after 1986 (Bewster/Rindfuss 2000; Adsera 2004, Kravdal/Rindfuss 2008), so countries where more women were involved in paid work had higher fertility rates than those where women were less frequently employed. In this context, attention has been devoted to analysing the effects of labour market characteristics on women's fertility levels, showing the relevance of unemployment levels, barriers to reassume paid work after parental leave, type of contracts, availability of part-time jobs, and, more generally, job insecurity for fostering postponement of maternity and lower levels of fertility (Ahn/Mira 2002; Ekert-Jaffé/Hoshi/Lynch/Mougin/Rendal 2002; Meron/Wimer 2002; Adsera 2004; Matysiak/Vignoli 2008; Bernardi/Klärner/von der Lippe 2008). Policies for balancing working and family lives, or greater job security derived from a flexible labour market, would account for higher fertility rates in countries where women's employment is high (Adsera 2004; Muszynska 2007; Matysiak/Vignoli 2008).

The aim of this paper is to analyse, in the context of family planning, how geographic mobility derived from specific working conditions (for short: mobility), as has been defined in the article by Lück and Schneider in this volume, affects parenthood decisions of the involved persons. In particular, in a first part we will examine whether job mobility fosters childlessness and/or postponement of childbearing, first on an aggregate level and 
then differentiating by mobility type. Based on the family size of mobile people whose reproductive period has ended, we will also speculate about whether the observed postponement strategy could translate into lower family size. In a second part we will focus not only on the effects of mobility but analyse also how the specific working conditions of mobile people and their resources for balancing working and private lives affect their parenthood decisions.

The analysis will be performed at a micro level. We will not perform a cross-country comparative analysis, as those cited above, but will analyse the mobility experience of working people in the six countries of our database on an aggregate level. As the database we have at hand provides only cross-sectional data, though with retrospective information, we can perform the analysis only with regard to comparing different relevant groups and inferring the corresponding impact. Although fertility patterns change over time and parenthood decisions change with age, controlling for age and comparing homogenous age groups provide reliable information about the effects of the circumstances of job mobility on family development.

As parenthood decisions, in the context of family planning, are made mostly by balancing pros and cons of the decision, taking into account the personal circumstances of the individuals, we will analyse only those cases where individuals are living in a partnership or have ever lived together with a partner longer than one year. Although, in the context of the individualisation process, parenthood and partnership have been differentiated so that it is no longer necessary to have a partner to become a parent, continuous partnership is a key condition when deciding on parenthood for most people. As individuals with no partnership cohabitation experience are overrepresented among mobile people (Schneider/Meil 2008), the decision to exclude them from the analysis is not ideologically driven, but was made to make more evident the effects of mobility on family development and avoid the necessity of controlling systematically by partnership status.

The data are drawn from "Job Mobilities and Family Lives in Europe", a survey of people living in six European countries (Germany, France, Spain, Switzerland, Poland, and Belgium) and representative at the national level of people aged 25 to 54 . Spatially mobile people were oversampled in order to get a minimum of 400 people per country, so that overall sample size includes 7220 interviews. A design weight corrects the oversampling for descriptive analyses. The survey was conducted by phone during the first half of 2007 (Lück/Schneider in this issue; Huynen/Montulet/Hubert/Lück/Orain 2008; Huynen/ Hubert/Lück 2010).

\section{Geographical job mobility and its effects on parenthood decisions}

Mobile people are more often childless than non-mobile people (27 and $43 \%, \mathrm{p}=.000$ ) people, and if they have children, they also have fewer (1.96 and 2.12, $\mathrm{p}=.005)$. But these differences are strongly conditioned by age and gender, as well as by partnership status. As gender is a key dimension, we will analyse the impact of mobility on family development differentially for men and women. 


\section{Men's mobility and its effects on parenthood decisions}

Men who have ever lived or are living together with a partner tend to be more often childless if they are mobile than otherwise ( 31 and $22 \%, \mathrm{p}=.001$ ), but if they have children, they do not have fewer (2.06 and 2.07). Mobile men also tend to be more often childless if they possess university degrees than otherwise (42 and $26 \%, \mathrm{p}=.000$ ), and if they do have children, they have fewer (1.96 compared to 2.10 otherwise, $\mathrm{p}=.05$ ). In principle then, mobility seems to foster childlessness among men. But mobility patterns are strongly conditioned by age (Schneider/Meil 2008), as is fertility. Many mobile people use mobility as a strategy for advancement in their labour and professional careers, mainly during the first stages of their involvement in the labour market. Once they have stabilised their position in the career, in the market, or in their working organisation, they give up their mobility (Bonnet/Orain 2010). Thirty-nine percent of mobile men are aged 35 or less, while that is only the case for $30 \%$ of non-mobiles, and, in Poland and Spain, the figures are $56 \%$ and $52 \%$, respectively.

Table 1: Percentage of childless men by age and mobility experience

\begin{tabular}{|c|c|c|c|c|}
\hline & Never-mobile & Past-mobile & Mobile & Total \\
\hline $25-29$ & 51 & 67 & 67 & $60+$ \\
\hline $30-34$ & 28 & 36 & 53 & $36^{* * *}$ \\
\hline $35-39$ & 27 & 35 & 28 & 29 \\
\hline $40-44$ & 17 & 10 & 15 & 14 \\
\hline $45-49$ & 14 & 14 & 11 & 14 \\
\hline $50-54$ & 9 & 15 & 11 & 11 \\
\hline Total & 22 & 25 & 31 & $25^{\star \star \star}$ \\
\hline
\end{tabular}

Note: The difference of each cell till 100 is the proportion of men who have children. Men who have ever lived or are living with a partner in a common household. $+\mathrm{p}<.10, * \mathrm{p}<.05, * * \mathrm{p}<.01, * * * \mathrm{p}<.001$. Weight: w_equal

Source: Job Mobilities and Family Lives in Europe 2007.

However, this difference in childlessness disappears after controlling for age. While, among men younger than 35 , those who are mobile are more often childless, among older men, there is no difference (cp. Table 1). The difference according to educational level also disappears after controlling for age. Men who were mobile in the past, but not when the interview was performed, when younger than 35 , are also more often childless than non-mobiles, but differences disappear also among older men. Although fertility changes over time and the data we are analysing are cross-sectional, these results suggest that mobile men are postponing their paternity rather than renouncing it because of job mobility, whatever their educational level.

The subjective evaluation of the involved men reinforces this interpretation. Asked about whether their working conditions had some role in their being childless, mobile men living in a partnership and younger than 35 state more often than past-mobiles and even more frequently than never-mobiles that their working conditions had at least some influence in their being childless $(55 \%$ of mobiles, $50 \%$ of past-mobiles, and $40 \%$ of never-mobiles, $\mathrm{p}=.11$ ). Among men older than 35 , on the contrary, there are no statistically significant differences between the different mobility experiences. 
The age at which mobile men had their children also confirms the postponement strategy of mobile men. Controlling for the age at which mobile men became fathers and their mobility situation at the moment, a fact that we can control for because we created a mobility biography for mobile people, we observe that men who were mobile before they had their first child, were 3.1 years older than those who were mobile after fatherhood and 2.5 years older than never-mobiles. Even though there are strong differences according to the educational level, as is well known (among others, Blossfeld/Huinink 1991), these differences hold for all main educational groups (cp. Table 2). Men who became mobile after having become fathers, on the contrary, did not postpone their parenthood decision, as compared to other fathers; they were even about one year younger than never-mobiles. The same pattern of postponement of fatherhood derived from mobility can also be observed for the age at second parenthood, again for all educational levels. Therefore, couples in which men are mobile tend to postpone parenthood decisions further than other non-mobile couples, irrespective their educational degree, yet mobile men with a lower educational level tend to have children earlier than mobiles with higher degrees.

Table 2: Mean age at first and second parenthood of men by different mobility experiences

\begin{tabular}{|c|c|c|c|c|c|c|}
\hline & \multicolumn{3}{|c|}{ First child } & \multicolumn{3}{|c|}{ Second child } \\
\hline & $\begin{array}{l}\text { Less tertiary } \\
\text { degree }\end{array}$ & $\begin{array}{l}\text { Tertiary } \\
\text { degree }\end{array}$ & Total & $\begin{array}{l}\text { Less tertiary } \\
\text { degree }\end{array}$ & $\begin{array}{l}\text { Tertiary } \\
\text { degree }\end{array}$ & Total \\
\hline Mobiles & 27.2 & 29.7 & $28.0^{* * *}$ & 29.9 & 31.8 & $30.5^{\star *}$ \\
\hline Child born before mobile & 26.2 & 28.6 & $26.9^{* \star *}$ & 29.2 & 30.0 & $29.3+$ \\
\hline Child born while mobile & 29.3 & 31.8 & $30.2^{* * *}$ & 31.3 & 33.8 & $32.2^{* * *}$ \\
\hline Past-mobiles & 27.1 & 29.6 & $27.9^{* \star *}$ & 29.8 & 32.7 & $30.4^{* \star *}$ \\
\hline Never-mobiles & 27.3 & 29.5 & $27.8^{* * *}$ & 30.3 & 32.2 & $30.8^{* * *}$ \\
\hline Total & 27.2 & 29.6 & $27.9^{* * *}$ & 30.0 & 32.3 & $30.6^{* * *}$ \\
\hline
\end{tabular}

Note: Men who have ever lived or are living with a partner in a common household. $+\mathrm{p}<.10 . * \mathrm{p}<.05$. $* * \mathrm{p}<.01 .{ }^{* * *} \mathrm{p}<.001$. Weight: $\mathrm{w} \_$equal

Source: Job Mobilities and Family Lives in Europe 2007.

The subjective perception of involved persons is also quite coherent with this result. So the proportion of mobile and past-mobile men who state that they had their children later than initially planned for job-related reasons is twice as big as among never-mobiles, yet not very widespread $(12 \%$ of mobiles, $12 \%$ of past-mobiles, and $5 \%$ of never-mobiles, $\mathrm{p}=.000$ ). Those who became fathers while mobile make this statement more frequently than those who began their mobility after their first child was born, though differences are not statistically significant at conventional levels (14 and $11 \%, p=.30)$. Further, the proportion of men in their typical reproductive age (younger than 40 years) who acknowledge that they are currently postponing having more children for job-related reasons also show that mobile men postpone their fertility decisions more often than never-mobiles ( $10 \%$ of mobiles, $13 \%$ of past-mobiles, and $5 \%$ of never-mobiles, $\mathrm{p}=.003$ ). 
Table 3: Mean number of children of fathers by mobility status

\begin{tabular}{lcccccc}
\hline & Never-mobiles & Past-mobiles & All mobile & $\begin{array}{c}\text { mobiles } \\
\text { 1st child } \\
\text { before mobile }\end{array}$ & $\begin{array}{c}\text { 1st child } \\
\text { while mobile }\end{array}$ & Total \\
\hline $25-29$ & 1.39 & 1.25 & 1.27 & 1.36 & 1.13 & 1.33 \\
$30-34$ & 1.80 & 1.57 & 1.54 & 1.72 & 1.31 & $1.68+$ \\
$35-39$ & 2.06 & 1.78 & 2.14 & 2.25 & 1.77 & $1.99^{*}$ \\
$40-44$ & 2.15 & 2.39 & 2.10 & 2.27 & 1.84 & $2.24^{*}$ \\
$45-49$ & 2.13 & 2.22 & 2.37 & 2.41 & 1.99 & 2.20 \\
$50-54$ & 2.34 & 2.10 & 2.30 & 2.39 & 2.10 & 2.26 \\
\hline Total & 2.08 & 2.05 & 2.06 & 2.21 & 1.73 & 2.07 \\
\hline
\end{tabular}

Note: Childless men are not counted to calculate the mean. Men who have ever lived or are living with a partner in a common household. $+\mathrm{p}<.10 .^{*} \mathrm{p}<.05 .{ }^{* *} \mathrm{p}<.01 .{ }^{* * *} \mathrm{p}<.001$. Weight: $\mathrm{w}$ equal and w_mob_equal

Source: Job Mobilities and Family Lives in Europe 2007.

The postponement of fertility decisions often translates into a smaller family size (among others, Kohler/Billari/Ortega 2002), but this seems not to be the case among most mobile men. While among younger generations aged less than 35 , mobile fathers and those who were mobile in the past have fewer children than those who were never mobile as a consequence of the postponement strategy, among older generations, there are no significant differences between different mobility experiences (cp. Table 3). This result holds also when controlling for educational level (results not shown). However, men who fathered their children while mobile tend to have fewer children than other mobiles and nevermobiles, whatever their age, which implies that only when mobility holds for very long periods and begins before the building of a family does it translate into smaller families. Therefore, recurring mobiles (Long-distance commuters, Overnighters and Multi-mobiles) are at greater risk of having smaller families. But as this longstanding mobility experience affects only a small proportion of all mobile people, most mobile men have no smaller families than other men with partnership experience.

Summarising, if we analyse real family size as well as the subjective evaluations of men who cohabit or have cohabited with a partner, mobility tends to postpone parenthood decisions so that mobiles and past-mobiles are more often childless at younger ages than never-mobiles. When they become parents, only when the decision was made while mobile were they much older than other men (about 2 years), but not when mobility began after the transition into parenthood. The postponement of the transition into parenthood does not necessarily translate into a smaller family, as can be deduced from the comparison of family size and the subjective evaluation of older men according to their mobility experience. Only men who were mobile before becoming a parent and stay mobile over time tend to have smaller families.

\section{Women's mobility and its effects on maternity decisions}

Mobile women who have cohabited or are cohabiting with a partner are much more frequently childless than never-mobiles and past-mobiles (40,15 and 17\%, p=.000) and also 
more often than mobile men (41 compared to $31 \%, \mathrm{p}=.000$ ). This pattern holds for all age groups (with the exception of 45-49), while women who were mobile in the past do not renounce maternity more often than never-mobiles (cp. Table 4). These results suggest that mobility hinders maternity decisions, forcing many women who want to become mothers to give up their mobile job. We have not collected data about the reasons for giving up mobility, but the fact that there are no significant differences in childlessness among women who were mobile in the past and those who never experienced mobility supports this interpretation. In addition, the fact that the proportion of mobile women, being much lower than that among men, decreases sharply with age in all countries (Schneider/Meil 2008), also suggests that a sizeable proportion of women give up mobility in order to achieve a better balance between private and working life. The higher the educational level, the more frequently mobile women are childless $(55 \%$ among those with a tertiary degree, as compared to $30 \%$ without, $\mathrm{p}=.000$ ), a relationship that remains stable for most age groups (with the exception of women older than 45).

Table 4: Percentage of childless women by age and mobility experience

\begin{tabular}{|c|c|c|c|c|}
\hline & Never-mobile & Past-mobile & mobile & Total \\
\hline $25-29$ & 53 & 39 & 79 & $53^{* * *}$ \\
\hline $30-34$ & 13 & 26 & 46 & $20^{* * *}$ \\
\hline $35-39$ & 11 & 18 & 32 & $15^{\star *}$ \\
\hline $40-44$ & 8 & 8 & 19 & 9 \\
\hline $45-49$ & 10 & 15 & 19 & 12 \\
\hline 50-54 & 6 & 6 & 19 & $7+$ \\
\hline Total & 15 & 17 & 40 & $18^{* * *}$ \\
\hline
\end{tabular}

Note: Women who have ever lived or are living with a partner in a common household. $+\mathrm{p}<.10 .{ }^{*} \mathrm{p}<.05$. $* * \mathrm{p}<.01 .{ }^{* * *} \mathrm{p}<.001$. Weight: $\mathrm{w} \_$equal

Source: Job Mobilities and Family Lives in Europe 2007.

Subjective evaluations about the reasons for not having children also point in this direction. Among women aged less than 35, more mobile than never mobile women with partnership experience state that their career has at least some importance in their being childless ( 65 and $51 \%, \mathrm{p}=.11)$. This is also frequently true among those who were mobile in the past (61\%). Among older women, where the proportion of those who are mobile is low (around $6 \%$ in the different age groups), there is however no difference according to mobility experience. In this case, educational level does not play a significant role, as there are no statistical significant differences between both educational levels, both for younger $(\mathrm{p}=.38)$ and older women $(\mathrm{p}=.58)$. Therefore, while, among men, mobility fosters postponement of fertility decisions but not childlessness, among women, it fosters postponement and childlessness, particularly among well-educated professional women, but also among those with lower educational degrees.

Among women, mobility fosters not only childlessness but also postponement of fertility decisions with similar patterns as seen among men. Women who were mobile when they had their first child were aged around 2.8 years older than never-mobiles, the same amount as among mobile men, but (unlike among men) more when they had a university degree than otherwise ( 2.5 years, as compared to 1.7 years older than never-mobiles). 
Those who became mobile after they became mothers, on the contrary, were younger $(0.6$ years, as compared to never-mobiles). Past-mobile women, unlike men, have also postponed their transition to motherhood around one year, particularly those with higher professional skills. The same pattern can also be found in the case of the second child. Despite this postponement in childbearing, mobile women do not tend to compensate through a strategy of concentration of their reproductive period, having therefore higher parity children later than other women (cp. Table 8).

Subjective evaluation also supports the conclusion that mobile women with partnership experience and children have postponed maternity. Mothers in their typical reproductive period (younger than 40 years old) state more frequently that they are postponing having more children because of their career when they are mobile than non-mobile (20 and $7 \%, \mathrm{p}=.000$ ), irrespective of their age and the time when the first child was born $(p=.46)$. This result also holds if we split non-mobile women between those who have a paid job and those who do not: Mobile mothers postpone having children nearly three times more often than working non-mobile mothers (20 and $8 \%, p=.000)$. However, those who were mobile in the past do not state more frequently than never-mobiles that they are postponing having another child ( 9 and $7 \%, \mathrm{p}=.34$ ). In general, mobile and past-mobile mothers state more frequently than never-mobiles that they had their children later than initially planned because of their career $(16,15$, and $9 \%, p=.000)$, which holds roughly for all age groups. However, women who had their first child while mobile do not state more frequently that they are currently postponing having more children $(p=.46)$, nor that their children were born later than initially planned $(p=.66)$, even if they had them much later.

Table 5: Mean age at first and second parenthood of men by different mobility experiences

\begin{tabular}{|c|c|c|c|c|c|c|}
\hline & \multicolumn{3}{|c|}{ First child } & \multicolumn{3}{|c|}{ Second child } \\
\hline & $\begin{array}{l}\text { Non tertiary } \\
\text { degree }\end{array}$ & $\begin{array}{l}\text { Tertiary } \\
\text { degree }\end{array}$ & Total & $\begin{array}{l}\text { Non tertiary } \\
\text { degree }\end{array}$ & $\begin{array}{l}\text { Tertiary } \\
\text { degree }\end{array}$ & Total \\
\hline Mobiles & 25.0 & 28.0 & $26.0^{* * *}$ & 27.5 & 31.2 & $28.6^{\star \star *}$ \\
\hline Child born before mobile & 24.5 & 26.9 & $25.2^{* \star *}$ & 26.3 & 30.1 & $27.2^{\star \star \star}$ \\
\hline Child born while mobile & 26.6 & 29.7 & $28.1^{\star \star *}$ & 30.5 & 32.5 & $31.3^{* * *}$ \\
\hline Past-mobiles & 25.6 & 28.9 & $26.4^{\star \star *}$ & 28.2 & 30.9 & $28.8^{* * *}$ \\
\hline Never-mobiles & 24.9 & 27.1 & $25.3^{* \star *}$ & 27.6 & 29.7 & $28.1^{* * *}$ \\
\hline Total & 25.1 & 27.7 & $25.7^{\star * *}$ & 27.8 & 30.2 & $28.3^{\star * *}$ \\
\hline
\end{tabular}

Note: Women who have ever lived or are living with a partner in a common household. $+\mathrm{p}<.10 . * \mathrm{p}<.05$. $* * \mathrm{p}<.01 . * * * \mathrm{p}<.001$. Weight: $\mathrm{w} \_$equal and $\mathrm{w} \_$mob_equal.

Source: Job Mobilities and Family Lives in Europe 2007.

If we consider the family size of those who have children, mobile mothers have fewer children than mobiles in the past (1.82 and 2.05, $\mathrm{p}=.06)$ and fewer than never-mobiles (2.17, $\mathrm{p}=.001)$. Mobiles in the past also have fewer than those who never experienced mobility $(\mathrm{p}=.06)$. This pattern holds for both women who became mothers while mobile as well as for those who became mobile after bearing their first child, but only till they are around 40 years old. On the other hand, among older women, there are no statistically significant differences among the age groups at conventional levels. But if we broaden 
somewhat the statistical significance level, we can observe that mobile mothers have fewer children than non-mobile mothers $(2.08$, as compared to $2.27, \mathrm{p}=.19$, among women older than 40), particularly when they became mothers while mobile. These results suggest a postponement of fertility decisions among those women who have managed to balance their family life with mobility requirements. This also translates into a smaller family size if they remain mobile over time. The fact that women's mobility decreases steadily with age suggests that many mothers give up mobility in order to accomplish their family project and those who remain or become mobile at older ages are mainly those who can fulfil their family project and combine it with mobility. Mobile women with higher educational degrees are more affected by difficulties balancing their mobility, family, and work so that they tend to have a smaller family size than those with no tertiary degree ( 1.9 children, as compared to 2.1 among those older than $40, p=.16$; if we also include childless women when computing completed fertility, the negative impact on well-educated mobile women with partnership experience is even stronger, 1.4, as compared to $1.8, \mathrm{p}=.03$ ).

Table 6: Mean number of children of mothers by mobility status

\begin{tabular}{lcccccc}
\hline & Never-mobiles & Past-mobiles & $\begin{array}{c}\text { Mobiles } \\
\text { All mobiles }\end{array}$ & $\begin{array}{c}\text { 1st child } \\
\text { before mobile }\end{array}$ & $\begin{array}{c}\text { 1st child } \\
\text { while mobile }\end{array}$ & Total \\
\hline $25-29$ & 1.61 & 1.47 & 1.16 & 1.08 & 1.27 & $1.54++$ \\
$30-34$ & 1.96 & 1.75 & 1.59 & 1.69 & 1.18 & $1.88^{*}$ \\
$35-39$ & 2.21 & 1.99 & 1.65 & 1.58 & 1.57 & $2.12^{*}$ \\
$40-44$ & 2.24 & 2.19 & 1.76 & 1.97 & 1.80 & $2.20++$ \\
$45-49$ & 2.34 & 2.36 & 2.40 & 2.33 & 2.25 & 2.35 \\
$50-54$ & 2.32 & 2.15 & 1.96 & 1.98 & 1.79 & 2.25 \\
\hline Total & 2.17 & 2.05 & 1.82 & 1.88 & 1.62 & $2.12^{\text {*** }}$ \\
\hline
\end{tabular}

Note: Childless women are not counted to calculate the mean. Women who have ever lived or are living with a partner in a common household. $++<0.15 .+\mathrm{p}<.10 .{ }^{*} \mathrm{p}<.05 .{ }^{* *} \mathrm{p}<.01 .{ }^{* * *} \mathrm{p}<.001$. Weight: w_equal and w_mob_equal.

Source: Job Mobilities and Family Lives in Europe 2007.

Mothers whose reproductive periods have typically ended (i.e., older than 40) and who had a mobility experience state more frequently than never-mobiles that they have fewer children than initially planned because of their career: $17 \%$ of mobile women and $11 \%$ of women who were mobile in the past make this statement, as compared to $8 \%$ of those who never had a job that required high mobility $(\mathrm{p}=.06)$. The subjective perception of mobile women reinforces then the conclusion that women's mobility translates into smaller families.

As a general conclusion, therefore, among men mobility tends to foster a postponement of parenthood, but not always a smaller family size. Smaller family size occurs only among those with long-term mobility who were mobile before entering parenthood. Among women, long-term mobility more often implies childlessness and not only postponement but also smaller families. Women who give up their mobility before their reproductive period ends also tend to postpone maternity but neither end up with a smaller family size nor are more often childless. Further, mobile women with higher educational 
degrees tend to be more affected by the difficulties balancing mobility, family, and work so that they are more frequently childless and tend to have fewer children if they remain mobile over their family-building period.

\section{Differences by countries}

The negative impact of mobility on parenthood decisions can be found in all countries, though at different intensities. The postponement effect is particularly high among men in Switzerland and among women in Spain, but in terms of completed fertility the strongest impact can be found among mobile German women, who are much more frequently childless or have fewer children than non-mobile German women and mobile women in other countries.

Ages at first birth of children vary from country to country, but in all countries, mobile men with children postpone their parenthood decision if they are mobile before fathering a child, but if they become mobile afterwards, they have their children even earlier than never-mobiles in all countries but Switzerland. The length of the delay compared with never-mobiles varies greatly from one country to another, ranging from 0.9 years in Germany to a maximum of 6.5 in Switzerland, where a sizeable proportion of mobile men entered fatherhood when they were over 40 . With the exception of Switzerland, the delay tends to be higher in countries where mobile people are mainly younger, as is the case in Spain and Poland.

The family size of mobile men older than 40 (an age at which most men will have no more children) is not smaller than among never-mobiles of the same age in any country. The same happens among those who were mobile in the past. The only exception to this pattern seems to be Poland, where mobile men of those ages have 1.8 children compared with 2.2 among non-mobiles (including in the mean those without children, $\mathrm{p}=.05$ for unweighted data). Therefore, in most countries, men's mobility does not imply having fewer children than non-mobiles. Yet, mobile people at those ages who began fatherhood while mobile tend to have fewer children than non-mobiles in all countries for which there are enough cases to make the comparison (France, Spain, Switzerland, and Belgium). As a consequence, although in most analyzed cases men's mobility does not seem to be at the cost of the family life project, this is not the case in all countries or when mobility lasts for very long periods. 
Table 7: Family development indicators by mobility experience, gender and country

\begin{tabular}{|c|c|c|c|c|c|c|c|c|}
\hline & \multicolumn{4}{|c|}{ Mean age at first birth } & \multicolumn{4}{|c|}{$\begin{array}{l}\text { Mean number of children of people aged } \\
40+\text { (including childless) }\end{array}$} \\
\hline & (1) & $(2)$ & (3) & (1)-(3) & (4) & (5) & $(6)$ & $(4)-(5)$ \\
\hline & $\begin{array}{l}\text { Born while } \\
\text { mobile }\end{array}$ & $\begin{array}{l}\text { Born } \\
\text { before } \\
\text { mobile } \\
\end{array}$ & $\begin{array}{l}\text { Never } \\
\text { mobile }\end{array}$ & Delay & Mobile & Non-mobile & Total & Difference \\
\hline & \multicolumn{8}{|c|}{ Men } \\
\hline Germany & 29,2 & 26,7 & 28,3 & 0,9 & 1,9 & 2,0 & 2,0 & $-0,1$ \\
\hline France & 29,2 & 26,2 & 28,1 & 1,1 & 2,1 & 2,1 & 2,1 & 0,0 \\
\hline Spain & 31,6 & 28,0 & 29,0 & 2,6 & 1,8 & 1,6 & 1,6 & 0,2 \\
\hline Switzerland & 34,7 & 31,6 & 28,2 & 6,5 & 1,9 & 2,0 & 2,0 & $-0,1$ \\
\hline Poland & 28,3 & 24,9 & 26,2 & 2,1 & 1,8 & 2,2 & 2,1 & $-0,4$ \\
\hline Belgium & 29,3 & 26,6 & 28,0 & 1,3 & 2,3 & 1,9 & 2,0 & 0,4 \\
\hline \multirow[t]{2}{*}{ Total } & 30,3 & 26,9 & 27,8 & 2,5 & 2,0 & 2,0 & 2,0 & 0,0 \\
\hline & \multicolumn{8}{|c|}{ Women } \\
\hline Germany & 29,5 & 26,2 & 25,4 & 4,1 & 1,1 & 2,0 & 2,0 & $-0,9$ \\
\hline France & 27,5 & 26,7 & 25,2 & 2,3 & 1,8 & 2,2 & 2,1 & $-0,3$ \\
\hline Spain & 31,2 & 25,5 & 26,7 & 4,5 & 1,7 & 2,0 & 2,0 & $-0,3$ \\
\hline Switzerland & 27,8 & 26,1 & 26,7 & 0,9 & 1,6 & 1,9 & 1,9 & $-0,4$ \\
\hline Poland & 26,4 & 22,5 & 23,8 & 2,7 & 2,0 & 2,3 & 2,3 & $-0,3$ \\
\hline Belgium & 26,3 & 25,2 & 24,9 & 1,4 & 1,9 & 2,2 & 2,2 & $-0,3$ \\
\hline Total & 28,3 & 25,1 & 25,6 & 2,6 & 1,6 & 2,1 & 2,1 & $-0,5$ \\
\hline
\end{tabular}

Note: Due to the small number of cases, the mean number of children includes in this case also those without children. Weight: w_nation.

Source: Job Mobilities and Family Lives in Europe 2007.

In the case of women, mobility in all countries also fosters postponement of fertility decisions when they become mothers while mobile, but not otherwise, and this is true in some countries even more than among men. The length of the delay compared with never-mobiles also varies greatly from one country to another, ranging from 0.9 years in Switzerland to 4.5 in Spain. Among women, the delay tends also to be higher in countries where mobility is more prevalent among young people than otherwise (with the exception of Germany, where the delay of 4.1 years is high and mobility is not concentrated among young people). The postponement effect is stronger among women than among men in most countries, only in Switzerland it is less than among men. Differences however vary greatly from one country to another, ranging from 3.2 years in Germany to 0.3 years in Belgium.

Unlike among men, in all countries family size of mobile women older than 40 is smaller than among non-mobiles, either because they are more often childless, or because they have fewer children. The negative impact of mobility on fertility, however, varies from one country to another. Also counting in those who are childless, mobile women older than 40 have between 0.28 and 0.35 fewer children than non-mobiles, while in Germany the difference is three times higher, reaching 0.94 children. The degree of negative impact does not seem conditioned by the scope of family-friendly policies developed in different countries, as countries with very different approaches to the work-family challenge show similar negative impacts (e.g., France compared with Spain, Belgium 
compared with Poland). In all countries, then, but particularly in Germany, mobility for women is at the cost of not having children or of having fewer than non-mobiles, either because those who are mobile decide so in light of difficulties to balance mobility, work, and family, or because becoming mobile is manageable only when they have no children or only a few.

\section{Mobility type and parenthood decisions}

Besides gender, the effects of mobility on family development also differ by mobility type $^{1}$. Relocation derived from job requirements is strongly associated with childlessness, both for men ( $49 \%$ of recent relocators with partnership experience have no children) and women $(55 \%)$, due to the fact that this form of job mobility takes place mainly during the first stages of the working career (Bonnet/Orain 2010). Fifty-six percent of men who are recent relocators are aged 25 to 34 , a percentage that is even greater among women $(65 \%)$. The open question is whether this form of mobility fosters childlessness or rather if childless people are more willing to relocate for job-related reasons, as has been shown they are (Schneider/Meil 2008). Subjective evaluation of the people concerned indicates that relocating for job-related reasons plays a role in people's being childless, particularly among women, as $65 \%$ of recent relocator women who have or had a partner state that they have no children because of their career, as compared to $49 \%$ of never-mobiles. Among men, many recent relocators relate in some way their childlessness with their career $(48 \%)$, but not more than never-mobiles $(43 \%)$. These results suggest that relocation for job-related reasons could play some role in childlessness among women, but not among men, an interpretation that would be supported when we focus not only on people who have recently relocated ( 3 years before the interview) but also on those who relocated in the past. While men who have ever relocated for job-related reasons are not more often childless than others ( $23 \%$, as compared to $26 \%, \mathrm{p}=.23)$, women with such an experience are more often childless $(21 \%$, as compared to $17 \%, \mathrm{p}=.05)$.

When recent relocators become parents after relocation, they are much older than never-mobiles, but not necessarily much older than other mobiles. Only recent relocator men enter parenthood later than other mobiles (when they were 32.5 years old, as compared to 30.2 years old for all mobile men), while this was not the case among women (27.6 years old, as compared to 28.1 years old for all mobile women). Further relocation for job-related reasons is not associated with a smaller family size. As this form of mobility is so strongly conditioned by age and, unlike other mobility forms, is usually a discrete event and not a recurring experience, the comparison of mean number of children is misleading. Most recent relocators will not have finished their reproductive period when they relocate. For those who do it at older ages, unlike serial relocators, it is likely that they will not be affected by relocation during their family-building period. Therefore, the fact that recent relocators older than 40 do not have fewer children than never-mobiles, irrespective of whether it is a man's or a woman's job that causes the move, cannot be interpreted as evidence that relocation does not affect family size. But if we consider all peo-

1 For the definition of the different mobility types, see Lück and Schneider's article in this volume. 
ple who have ever experienced relocation for a job-related reason, we can observe that they do not have fewer children than other people, neither men ( 2.1 in both cases) nor women $(2.0$, as compared to 2.1 , cp. Table 8$)$.

Therefore, relocation for job-related reasons is associated with greater childlessness among women but not men; in both cases, it generates a postponement of parenthood decisions, but does not seem to translate into a smaller family size among those who have children.

Overnighting is the mobility pattern that is most affected by gender, as it is mostly a male phenomenon ( $86 \%$ of all overnighters are men), while not conditioned by age for either men $(p=.78)$ or women $(p=.57)$. The effects of frequent and continuous overnighting out of the home on family development for men is small, as it is not associated either with childlessness or with a smaller family size (there are no statistically significant differences on both dimensions either considering all ages or only people older than $40-\mathrm{cp}$. Table 8). The only sizeable effect is that when the first child is born while mobile in this form, the age of the transition into parenthood is much later than among never-mobiles (29.7 years old, as compared to 27.8 years old), but not later than among other mobiles who father their children while mobile (30.2). However, when this form of mobility is maintained during the whole family-building period, it tends to translate into a smaller family size (1.7 children among those who are mobile before parenthood, as compared to 2.4 among those who become overnighters after building a family, $\mathrm{p}=.000, \mathrm{cp}$. Table 8 ).

Table 8: Main family development indicators by mobility type

\begin{tabular}{|c|c|c|c|c|c|c|}
\hline & LDC & OV & $\mathrm{RR}$ & MM & Total & N-M \\
\hline \multicolumn{7}{|l|}{ Men } \\
\hline$\%$ childless $25-54$ & 26 & 28 & 49 & 35 & $31^{* * *}$ & 22 \\
\hline$\%$ childless $40+$ & 10 & 13 & 24 & 8 & $12^{*}$ & 13 \\
\hline Mean age at first birth & 28.3 & 27.5 & 28.3 & 28.0 & 28.0 & 27.8 \\
\hline Born before being mobile & 27.0 & 26.0 & 28.3 & 26.9 & $26.9^{* *}$ & \\
\hline Born while mobile & 30.4 & 29.7 & 32.5 & 29.4 & 30.2 & \\
\hline Mean age at second birth & 30.9 & 29.4 & 29.1 & 32.2 & $30.3^{\star \star \star}$ & 30.7 \\
\hline Time lag between first and second child & 3.5 & 3.0 & 2.8 & 4.2 & $3.3^{* * *}$ & 3.5 \\
\hline Mean number of children $25-54$ & 2.06 & 2.1 & 2.05 & 2.05 & 2.1 & 2.1 \\
\hline Mean number of children $40+$ & 2.31 & 2.15 & 2.54 & 2.24 & 2.27 & 2.19 \\
\hline \multicolumn{7}{|l|}{ Women } \\
\hline$\%$ childless $25-54$ & 31 & 40 & 55 & 62 & $40^{\star * *}$ & 15 \\
\hline$\%$ childless $40+$ & 20 & : & 29 & 33 & 20 & 8 \\
\hline Mean age at first birth & 26.4 & 24.5 & 25.9 & 26.2 & $26.0^{*}$ & 25.3 \\
\hline Born before being mobile & 25.4 & 24.0 & 25.9 & 23.8 & 25.2 & \\
\hline Born while mobile & 28.3 & 26.1 & 27.6 & 28.6 & 28.1 & \\
\hline Mean age at second birth & 29.1 & 26.7 & 28.0 & 28.1 & $28.5^{\star}$ & 28.0 \\
\hline Time lag between first and second child & 4.0 & 2.9 & 3.9 & 4.0 & 3.8 & 3.5 \\
\hline Mean number of children $25-54$ & 1.8 & 2.0 & 1.7 & 1.5 & 1.8 & 2.2 \\
\hline Mean number of children $40+$ & 2.1 & 2.1 & 2.3 & 1.8 & 2.1 & 2.3 \\
\hline
\end{tabular}

Note: $\mathrm{LDC}=$ Long-distance commuter. $\mathrm{OV}=$ Overnighter. $\mathrm{RR}=$ Recent Relocator. $\mathrm{MM}=$ Multi-mobile. $\mathrm{N}-\mathrm{M}=$ Never-mobile. ${ }^{*} \mathrm{p}<.05 .{ }^{* *} \mathrm{p}<.01 .{ }^{* * *} \mathrm{p}<.001$. Significance levels refer to the comparison between the different mobility types. Weight: w_equal and w_mob_equal.

Source: Job Mobilities and Family Lives in Europe 2007. 
In the case of women, the fact that there are so few with this mobility pattern, unlike other forms (14\% of overnighters, as compared to $38 \%$ of other mobility types, are women, $\mathrm{p}=.000$ ) suggests that it is hardly compatible with family life projects so that most women are not really willing to accept this mobility requirement. Those who are mobile in this form are more often childless than never-mobiles ( $40 \%$, as compared to $15 \%)$ and than men (28\%), but we cannot extrapolate whether this translates into lower completed fertility, as there are not enough cases among older women. As with men and other mobile women, they also postpone their transition to motherhood if they were mobile before bearing a child, but this postponement is much shorter than among other forms of mobility ( 0.8 years, as compared to 2.8 years) and among men ( 1.9 years). However, the family size of these mobile women is not smaller than that of other women, irrespective of age and mobility status when the transition to motherhood occurred. $(\mathrm{p}=.69)$.

In the case of long-distance commuting (LDC), we can observe a similar pattern as among overnighters, but without so intense negative effects on family development for women. LDC men are not more frequently childless than never-mobiles, nor do they have a smaller family size, but postpone parenthood while they are mobile before fathering their first child (2.6 years later than never-mobiles). Men who are LDC throughout their family-building period tend, however, to have fewer children (2.0 among those who entered fatherhood while LDC, as compared to 2.4 among those who entered afterwards).

LDC women are more often childless, even at later ages. If they have children, they have fewer than never-mobiles, though the difference in family size disappears among older women, which can be interpreted in the sense that this type of mobility does not foster a smaller family size among women. Unlike among men, the mobility status when the transition to motherhood occurred does not affect the final number of children. However, the postponement effect is strong (3.0 years), even more so than when they are overnighters or than among men.

Multi-mobility is a mobility form that appears mostly at young ages among women (65\% are aged 25-34), but not among men, where it is not so strongly related with age. Additionally, it is not so uncommon among women as could be expected, as $1 \%$ of working women are multi-mobile, as compared to $2 \%$ of working men, not having statistically significant differences according to gender $(p=.29)$. Multi-mobility is associated with higher levels of childlessness, both among men and women, but controlling for age it can be observed only for women. As other forms of mobility, it implies a postponement of the transition to parenthood, but not more than other mobility types, neither among men nor women. However, when they have more than one child, the time lag between the first and second child tends to be larger than among never-mobiles and, among men, also more than other mobility types. However, the family size of multi-mobile men is not affected by the specificities of this type of mobility, while, in the case of women, it is also associated with smaller families. Therefore, while, among men, this mobility form only generates a postponement of family development, in the case of women, it also generates childlessness and a smaller family size.

All in all, the effects of mobility on family development are far stronger along the gender dimension than according to mobility type. For men, no mobility type appears to have stronger effects on family development than others. The most relevant dimension for assessing the impact is not the specific form that mobility takes, but the duration of the mobil- 
ity experience during the family-building process and whether mobility happens before or after entering parenthood. If mobility becomes a lifestyle that holds for very long periods and begins early in the individual's working life, this tends to translate into late parenthood and the building of a smaller family, irrespective of the form it takes. For women, besides the stronger impact on their family life project, only LDC seems to have a smaller impact in terms of childlessness and family size; all other forms show self-selection processes concentrating the mobility experience to younger ages and abandoning mobility to fulfil family aspirations and lead to more frequent childlessness and/or smaller families.

\section{Working conditions, gender, and family development among mobile people}

In this section, we will analyse the effects of specific working conditions and employer measures to promote a better balance between working and private lives on childlessness and postponement of parenthood. Although parenthood decisions do not require having a partner, we will focus on cohabiting partners because we want to analyse the impact of the partner's working conditions as well as the impact of his or her role in housework. We assume that parenthood decisions are made conditioned by the evaluation of the possibilities of balancing working and family lives. In this context, the partner's working conditions and cooperation between partners could play a relevant role, particularly in the case of women, but also in the case of men. It can be assumed that a mobile woman will be more prone to have children if the time she has to invest in work and mobility is not all-consuming and/or if she has some flexibility in organising her working time and/or if she can count on the collaboration of her partner. In the case of a mobile man, it can be assumed that he will be more prone to father a child, in the most traditional version, if he has a partner who can assume all the work of taking care of the children or, in a more egalitarian version, if he has time enough left from work to devote himself to his family obligations.

The analytical technique we will use is logistic regression analysis where we will first analyse how working conditions affect the odds ratio of the probability of not having children, as compared to the probability of having at least one child. Through this analysis, we will identify which working conditions are more associated with childlessness and which working conditions facilitate having children. Implicit to this analytic strategy is the assumption that everybody living in a partnership wants to have a child, which is only true for a proportion of childless couples, but not for all. As we have collected data on the subjective evaluation of how personal working experience affects fertility decisions, we will also analyse, for people living in a partnership without children, whether the fact of not having children is influenced by their working conditions ${ }^{2}$. In particular, we will analyse the odds ratio of the probability of stating that job-related reasons played an important or very important role in not having children, as compared to the probability that they did not play any significant role. The information we get through the analysis of this question is much more precise than just looking at who has children or not, as it also provides clues for causal interpretation. For the analysis of the postponement of fertility deci-

2 The question which was asked in the interview was: "How important are job-related reasons for the fact that you not have children? Are they not important at all, not important, important, or very important?" 
sions among people with children, we will use the question included in the questionnaire; it asked whether the interviewed person was postponing having more children because of his or her career. We will also perform a logistic regression analysis of the odds ratio of answering yes instead of no.

As control variables, we will introduce age as a continuous variable while educational level and (in the case of the estimation of the odds ratios of postponing fertility) the number of children will be treated as dummy variables, as we do not have enough cases to perform a more detailed analysis. As variables measuring working conditions, we will focus on the two most relevant variables of time investment in work. On one side, we will consider the time devoted to paid work: part time, when they invest less than 35 hours a week; full time, when they invest between 35 and 42 hours; and long hours, when they invest more than 42 . In the case of the partner's working time, we will also consider whether he or she has no paid work. As a reference point, we will take the situation when paid work is full time (35 to 42 hours a week), as it is quite common among job mobile people (44\%). Further, we will also consider the four mobility types we have analysed in the previous section; though in the case of the partner, we will distinguish only whether he or she has a mobile job or not.

As resources for balancing working and private lives, we will consider, on one side, those which are available at the working place and, on the other, those which are available in the private sphere. In the first category, we will focus on the most commonly considered measures of flexitime and teleworking possibilities (Riedmannn/Bielenski/Szczurow ska/Wagner 2006; Parent-Thirion/Fernández Macías/Hurley/Vermeylen 2007). But having an understanding supervisor is also particularly important (Meil/García Sainz/Luque/ Ayuso 2007; Rossi 2006; Meil/Ayuso/Mahía 2010), as it is he or she who controls and evaluates the work done by the employee and adjusts formal working conditions, generating more or less overload and margin to balance working and private obligations. To measure this kind of resource, we rely on perceived support, the feeling of being supported by the employer ${ }^{3}$, which we have collected only for mobile people. In the case of the self-employed, we consider that they feel supported by themselves. As resources available in the private sphere, we will include the involvement of both partners in housework, distinguishing whether housework is performed equally by both partners or mainly by the woman, according to the evaluation of the interviewed person.

As gender is a key dimension, we will perform and discuss our analysis separately for men and women, as we did before. In Table 9, we have collected the estimated odds ratios for our independent variables in the case of men. We have made the estimations not only for mobile men but also for all working men, irrespective of their mobility status.

\section{Men's working conditions and parenthood decisions}

Against a first impression that the workload has an important impact on the parenthood decisions of mobile men, the detailed analysis of the odds ratios reveal that, in most cases, how much time men devote to paid work (in the workplace and in the associated mobility) does not affect their family projects in a relevant manner.

3 The question in the questionnaire was, how well do you feel supported by your employer? Not at all, a little, reasonably well, or very well. 
Controlling for age, mobile men with a part-time job are more likely to be childless, to state that it is because of job-related reasons, and, when they have children (controlling for the number) to state that they are postponing having more children because of their career, as compared to full-time job mobiles. This pattern seems to reflect the persistence of some traits of the bread-winner role model, whereby a man has to earn a full income in order to be a proper father. But not all working men show this pattern, as can be seen in columns 4 and 6 of Table 9, which suggest that it could reflect more the economic situation of the couple than specific role models, because high mobility is associated with high financial and personal costs (Meil/Ayuso/Mahía 2010). In any case, only a small proportion of mobile men work part time (6\%, mostly younger ones).

Mobile men who have to work long hours, which is quite frequent (48\%), do not base their family life project on the time they have to devote to paid work. They are not more often childless than full-time mobiles, although those without children tend to attribute it more frequently to their career. But those with children are not postponing more often having one more child than full-time mobiles. Compared to all working men, mobiles do not appear to be more conditioned in their family planning by the time they have to invest in paid work than other men. In fact, non-mobile men working long hours tend to say much more often that they do not have children or are postponing having more children because of their career. Therefore, the time invested in paid work does not hinder the family development of mobile men more than others.

As we have seen before, mobile men are more often childless than non-mobiles, but, after controlling for age, this difference disappears, which suggests that the extra time they have to invest in their working life, taken from their private life, does not foster childlessness. This same result is confirmed in column 4 of Table 9. The type that this mobility adopts does not seem to play any significant role. So compared to long-distance commuters, who have to invest 2 hours a day in their commute between home and work, overnighters, who have to sleep very frequently away from home for job-related reasons (more than 60 times a year), are not more often childless, do not state more frequently that they have no children because of their career, or, if they have children, state more frequently that they are postponing (cp. Table 9, column 1). The same happens with multi-mobiles and non-mobiles (cp. Table 9, column 4). Only men (living in a partnership) who have relocated recently are more often childless, whatever their age, which suggests that relocation is much more probable when there are no children, as balancing relocation and family is associated with important adaptive costs for all family members (Green/Canny 2003).

The resources for balancing working and private lives have only a limited impact on facilitating the family development of mobile men. Ironically, those who enjoy flexitime are more likely to be childless, but they state more often that it is because of other reasons than their career (if we accept a significance level higher than the conventional 5\%) and it has no impact on the timing of having children. The same result can be observed if we consider the whole working population of men, which implies, according to our data, that this kind of measure in the case of men has no impact on family development. This does not mean that it does not help in balancing working and family lives (Parent-Thirion/Fernández Macía/ Hurley/Vermeylen 2007), as it reduces work overload and increases satisfaction (Meil/ Ayuso/Mahía 2010). 
Table 9: Odds ratios of the multivariate logistic regression analysis on parenthood decisions of men

\begin{tabular}{|c|c|c|c|c|c|c|}
\hline & \multicolumn{3}{|c|}{ Mobile men } & \multicolumn{3}{|c|}{ All working men } \\
\hline & $\begin{array}{l}\text { Has no } \\
\text { children }\end{array}$ & $\begin{array}{l}\text { No child be- } \\
\text { cause job } \\
\text { career }\end{array}$ & $\begin{array}{l}\text { Postponing } \\
\text { because job } \\
\text { career }\end{array}$ & $\begin{array}{l}\text { Has no } \\
\text { children }\end{array}$ & $\begin{array}{l}\text { No child } \\
\text { because job } \\
\text { career }\end{array}$ & $\begin{array}{c}\text { Postponing } \\
\text { because job } \\
\text { career }\end{array}$ \\
\hline Age & $0.86^{* * *}$ & $0.96+$ & 1.02 & $0.90^{* * *}$ & $0.97+$ & 0.92 \\
\hline \multicolumn{7}{|l|}{ Educational level } \\
\hline Ref.: Less than tertiary & 1 & 1 & 1 & 1 & 1 & 1 \\
\hline Tertiary & $1.7^{\star \star *}$ & 1.11 & $4.1^{\star \star *}$ & $1.49^{* *}$ & $0.61+$ & 0.86 \\
\hline \multicolumn{7}{|l|}{ Nr. Children } \\
\hline Ref.: 1 child & & & 1 & & & 1 \\
\hline 2 or more & & & $0.19^{* *}$ & & & $0.63++$ \\
\hline \multicolumn{7}{|l|}{ Work time } \\
\hline Part-time (34 or less) & $4.55^{\star * *}$ & $6.26^{\star \star *}$ & $6.15+$ & 1.30 & $2.81^{*}$ & 0.66 \\
\hline Ref.: Full-time (35-42) & 1 & 1 & 1 & 1 & 1 & 1 \\
\hline Exceeding $(43+)$ & 0.87 & $2.04^{*}$ & 0.81 & 0.91 & 1.71 & $2.68^{\star *}$ \\
\hline \multicolumn{7}{|l|}{ Mobility status all } \\
\hline Ref.: Non-mobile & & & & 1 & 1 & 1 \\
\hline LDC & & & & 1.06 & 0.98 & 0.70 \\
\hline Overnighter & & & & 1.14 & 1.09 & 1.14 \\
\hline Recent Relocator & & & & $1.93^{*}$ & 0.93 & 0.43 \\
\hline Multi-mobile & & & & 1.29 & 1.43 & 0.50 \\
\hline \multicolumn{7}{|l|}{ Mobility status } \\
\hline mobile & 1 & 1 & 1 & & & \\
\hline LDC & 0.92 & 0.76 & 2.07 & & & \\
\hline Overnighter & 0.82 & 1.32 & 3.19 & & & \\
\hline Recent Relocator & 1.28 & 0.71 & 1.11 & & & \\
\hline \multicolumn{7}{|l|}{ Multi-mobile } \\
\hline \multicolumn{7}{|l|}{ Flexi-time } \\
\hline Ref.: no possibility & 1 & 1 & 1 & 1 & 1 & 1 \\
\hline At least some & $1.31++$ & $0.64++$ & 0.58 & $1.25+$ & $0.64+$ & 0.65 \\
\hline \multicolumn{7}{|l|}{ Tele-working } \\
\hline Ref.: no possibility & 1 & 1 & 1 & 1 & 1 & 1 \\
\hline At least once a month & $0.72+$ & 0.83 & $3.11^{*}$ & $0.72^{*}$ & 1.39 & 1.01 \\
\hline \multicolumn{7}{|l|}{ Employer's support } \\
\hline Ref. no support & 1 & 1 & 1 & & & \\
\hline Supports mobility & 0.81 & 0.79 & $0.37+$ & & & \\
\hline \multicolumn{7}{|l|}{ Housework division } \\
\hline Ref. Woman does most & 1 & 1 & 1 & 1 & 1 & 1 \\
\hline Both equal or man more & $1.58^{* *}$ & $1.47++$ & $3.86^{* *}$ & 1.03 & 1.28 & 1.16 \\
\hline \multicolumn{7}{|l|}{ Work time partner } \\
\hline Not working for pay & $0.73++$ & & & $0.38^{* * *}$ & & \\
\hline Part-time (34 or less) & $0.46^{\star *}$ & & & $0.35^{\star * *}$ & & \\
\hline Full-time $(35-42)$ & 1 & & & 1 & & \\
\hline Exceeding $(43+)$ & $3.10^{* * *}$ & & & $1.43^{*}$ & & \\
\hline \multicolumn{7}{|l|}{ Partner mobile } \\
\hline Ref. not mobile & 1 & 1 & 1 & 1 & 1 & 1 \\
\hline Mobile & $1.90^{*}$ & $1.92+$ & 0.63 & $3.77^{* * *}$ & $1.97^{*}$ & $3.66+$ \\
\hline Number of cases & 1072 & 299 & 336 & 1773 & 397 & 579 \\
\hline Likelihood ratio & 926.5 & 340.0 & 137.7 & 1523.3 & 428.9 & 300.0 \\
\hline
\end{tabular}

Note: All men living in a common household with a partner. $++<0.15$. $+\mathrm{p}<.10 . * \mathrm{p}<.05$. $* * \mathrm{p}<.01$. $* * * \mathrm{p}<.001$. Weight: $\mathrm{w} \_$mob_equal.

Source: Job Mobilities and Family Lives in Europe 2007.

The effects of teleworking on family development are also unclear, as, on one side, mobile men who can work at least sometimes at home are less likely to be childless, but 
those who have no children attribute it to their career in the same proportion as those who cannot telework. On the other side, when they have children, it is much more likely that they are postponing the decision to have another one than those who have no possibility of working at home. Therefore, teleworking does not facilitate the family development of mobile men, nor does it for non-mobile men, which again does not imply that it does not help in balancing working and family lives. Although it does not reduce work overload, it increases satisfaction (Meil/Ayuso/Mahía 2010).

Despite the fact that flexitime and teleworking do not facilitate the family development of men, the perception of being supported by the employer facilitates the decision to have children: Mobiles who feel supported state less frequently that they are postponing having more children because of their career, and, if we accept significance levels higher than $5 \%$, they are also less often childless and state less frequently that it is due to their career. However, the results do not appear as strong as could be expected. Even policies designed by employers to support mobile men or an understanding work climate do not appear clearly to facilitate the parenthood decisions of mobile men, that does not mean that they do not help men to balance their working and family lives and that they do not reduce overload and increase satisfaction.

The implication of men in housework does not seem to facilitate family development among mobile men. On the contrary, it seems to hinder having children, as mobile men highly involved in housework are more often childless and state more frequently that it is because of their career; and, if they have children, they also state more often that they are postponing having more children. Egalitarian men seem to be overburdened by the workload derived from long working hours (working time plus the time invested in mobility) and the time invested in housework. However, most egalitarian men have children $(65 \%$, as compared to $86 \%$ of non-egalitarians, $p=.000)$. This negative effect of gender equality on family development seems to be a specific characteristic of mobile men because, among all working men, there are no statistically significant differences among the estimated odds ratios for any of the variables.

For the family development of mobile men, the working conditions of their partner are much more relevant than theirs. For mobile men whose partner has paid work, the more time she invests in paid work, the more likely it is that they are childless. However, mobile men whose partner is a homemaker do not more often have children than those whose partner works full time. If the partner is also mobile, the likelihood of being childless is also much higher, as the odds ratio is twice when she is not mobile. Compared to non-mobiles, the effects on the degree of involvement of the partner in paid work is more intense among mobiles than non-mobiles (cp. columns 1 and 4 in Table 9). The subjective evaluation of parenthood decisions is not relevant in this case because it refers to the working conditions of the interviewed, not of the partner.

Summarising, it can be said that the amount of time invested in paid work has no clear impact on the family development of mobile men, while the time invested in unpaid housework deter them from having children or induce them to postpone the decision. Egalitarian men are more often childless because of their career and are more likely to postpone having more children. Although flexitime and teleworking have ambiguous effects, a supportive work environment seems to facilitate their family life projects, though not in an unquestionable way. However, the factor that appears to be more relevant for the family development 
of partnerships where the man is mobile is the working time and mobility status of the partner, who usually has to assume more housework and childcare (Meil 2010).

\section{Women's working conditions and fertility decisions}

In the case of mobile women, the time they invest in paid work has much more impact on their family development than among men, and it appears as one the most relevant dimensions when mobile women decide on motherhood. The less time they devote to paid work, the lower the risk ratio of being childless and the less likely it is due to their career. The same could be expected in relation with postponing having one more child among those with children, but the significance level is too high to state it.

As has been discussed before, while, among men, the type of mobility is not relevant for its impact on family development, women in other forms of mobility than longdistance commuting have a greater likelihood of remaining childless, but not of postponing have more children due to their career.

Resources for improving the balance between work, mobility, and family do not seem to play an important role in facilitating family development. The possibility of having some flexibility in organising the workday is not associated with a lower risk ratio of being childless, rather the contrary, and it is neither associated with being childless or postponing having more children due to career. The possibility of doing some work at home is neither associated clearly with less childlessness nor reduces the probability of postponing having more children or not having any at all because of the career. In other terms, neither flexitime nor teleworking seems to facilitate mobile women's decisions on motherhood, which does not imply that these working conditions can contribute to feeling less frequently overloaded and/or more often satisfied, as they do (Meil/Ayuso/Mahía 2010). The incapacity of these kind of measures to facilitate motherhood is not derived from the specific working conditions of mobile women, but can also be found when working women are non-mobile, as can be observed in Table 10 (columns 4 to 6).

Despite these unsatisfactory results, the feeling of being supported by the employer does not seem to be completely irrelevant for the family development of mobile women. When they feel supported by their employer, it is less likely that they are childless and, if we broaden the significance level, also less likely to postpone having more children because of their career. Therefore, employers who have developed family-friendly policies for their mobile employees reduce not only the stress levels of their employees and increase their satisfaction with work (Meil/Ayuso/Mahía 2010) but also facilitate their family development, both of men as well as of women. If we compare the estimators for mobile men and women, we can observe that the impact is clearer in the case of women.

To have a collaborative partner at home does not seem to play any significant role in the fertility decisions of mobile women, as it is neither associated with lower risk ratios of being childless due to career nor of postponing having more children. The same result appears for all working women, which implies that men's involvement in housework does not facilitate the fertility decisions of women, and, as we have seen, it can even hamper them when men are mobile. With the emergence of the "negotiating family" (Nave-Herz 2003; Meil 2006), it seems that in the "negotiation" between partners when they decide to have a child, the involvement of men in housework does not play any significant role. Women, therefore, seem 
to decide on motherhood mostly without considering the predisposition of their partner to be actively involved in childcare, irrespective of whether they are mobile (cp. Table 10).

Table 10: Odds ratios of the multivariate logistic regression analysis on fertility decisions of women

\begin{tabular}{|c|c|c|c|c|c|c|}
\hline & \multicolumn{3}{|c|}{ Mobile women } & \multicolumn{3}{|c|}{ All working women } \\
\hline & $\begin{array}{l}\text { Has no } \\
\text { children }\end{array}$ & $\begin{array}{l}\text { No child } \\
\text { because job } \\
\text { career }\end{array}$ & $\begin{array}{l}\text { Postponing } \\
\text { because } \\
\text { job career }\end{array}$ & $\begin{array}{l}\text { Has no } \\
\text { children }\end{array}$ & $\begin{array}{c}\text { No child } \\
\text { because job } \\
\text { career }\end{array}$ & $\begin{array}{l}\text { Postponing } \\
\text { because job } \\
\text { career }\end{array}$ \\
\hline Age & $0.90^{* * *}$ & $0.96+$ & 1.06 & $0.88^{* * *}$ & 0.99 & 0.94 \\
\hline \multicolumn{7}{|l|}{ Educational level } \\
\hline Ref.: Less than tertiary & 1 & 1 & 1 & 1 & 1 & 1 \\
\hline Tertiary & $1.92^{* *}$ & 1.04 & 0.88 & $1.72^{\star \star \star}$ & 1.04 & 1.59 \\
\hline \multicolumn{7}{|l|}{ Nr. Children } \\
\hline Ref.: 1 child & & & 1 & & & 1 \\
\hline 2 or more & & & $0.23^{* *}$ & & & $0.51^{*}$ \\
\hline \multicolumn{7}{|l|}{ Work time } \\
\hline Part-time (34 or less) & $0.51^{*}$ & 0.57 & 1.34 & $2.21^{\star * \star}$ & $0.36^{*}$ & 1.08 \\
\hline Ref.: Full-time (35-42) & 1 & 1 & 1 & 1 & 1 & 1 \\
\hline Exceeding $(43+)$ & $1.71+$ & $1.90+$ & 1.15 & $3.60^{\star * *}$ & 1.19 & 1.18 \\
\hline \multicolumn{7}{|l|}{ Mobility status } \\
\hline Ref.: Non-mobile & & & & 1 & 1 & 1 \\
\hline LDC & & & & $1.73+$ & 1.70 & $2.81^{*}$ \\
\hline Overnighter & & & & $3.86^{\star *}$ & 1.80 & 1.30 \\
\hline Recent Relocator & & & & $1.90++$ & 1.92 & 1.90 \\
\hline Multi-mobile & & & & $5.23^{\star *}$ & $2.42++$ & 5.42 \\
\hline \multicolumn{7}{|l|}{ Mobility status } \\
\hline Ref.: LDC & 1 & 1 & 1 & & & \\
\hline Overnighter & $1.89^{*}$ & 0.91 & 0.60 & & & \\
\hline Recent Relocator & 1.15 & 0.87 & 1.07 & & & \\
\hline Multi-mobile & $3.24^{* *}$ & 1.51 & 1.57 & & & \\
\hline \multicolumn{7}{|l|}{ Flexi-time } \\
\hline Ref.: no possibility & 1 & 1 & 1 & 1 & 1 & 1 \\
\hline At least some & $1.51+$ & 0.88 & 0.61 & $1.29+$ & 0.73 & 0.67 \\
\hline \multicolumn{7}{|l|}{ Tele-working } \\
\hline Ref.: no possibility & 1 & 1 & 1 & 1 & 1 & 1 \\
\hline At least once a month & 0.79 & $2.23^{*}$ & 1.59 & $0.67^{*}$ & 1.30 & $3.00^{* *}$ \\
\hline \multicolumn{7}{|l|}{ Employer's support } \\
\hline Ref. no support & 1 & 1 & 1 & & & \\
\hline Supports mobility & 1.07 & $0.41^{*}$ & $0.53++$ & & & \\
\hline \multicolumn{7}{|l|}{ Housework division } \\
\hline Ref. Woman does most & 1 & 1 & 1 & 1 & 1 & 1 \\
\hline Both equal or man more & 0.98 & 1.18 & 1.35 & $1.29+$ & 0.77 & 1.02 \\
\hline \multicolumn{7}{|l|}{ Work time partner } \\
\hline Not working for pay & 0.47 & & & $1.93^{*}$ & $2.39+$ & $0.13++$ \\
\hline Part-time (34 or less) & 1.02 & & & 0.83 & 1.84 & $3.02^{*}$ \\
\hline Full-time (35-42) & 1 & & & 1 & 1 & 1 \\
\hline Exceeding $(43+)$ & 0.91 & & & $0.74+$ & $2.23^{* *}$ & 0.70 \\
\hline \multicolumn{7}{|l|}{ Partner mobile } \\
\hline Ref. not mobile & 1 & 1 & 1 & 1 & 1 & 1 \\
\hline Mobile & 1.12 & 0.74 & 0.64 & 1.18 & 0.66 & 0.77 \\
\hline Number of cases & 456 & 186 & 152 & 1372 & 187 & 527 \\
\hline Likelihood ratio & 480.3 & 233.7 & 130.6 & 1107.5 & 228.1 & 277.5 \\
\hline
\end{tabular}

Note: All men living in a common household with a partner. $++<0.15$. $+\mathrm{p}<.10 . * \mathrm{p}<.05$. $* * \mathrm{p}<.01$. *** $\mathrm{p}<.001$. Weight: $\mathrm{w} \_$mob_equal

Source: Job Mobilities and Family Lives in Europe 2007. 
This result is reinforced by the fact that the time invested by the partner in paid work has no significant effect on the fertility decisions of mobile women, neither on being childless, nor on postponing having more children. Even the fact that the partner is also mobile, that is both partners are mobile, seems not to have any relevant impact, which can be due to the fact that there are too few cases in this situation (15\% of cohabiting couples are both job mobile). At first glance, these results seem contradictory with those we have obtained analysing men's evaluations, but we have to keep in mind that mobile women are not the partners of mobile men. If we consider the analysis for all women, we can observe that the results we have obtained are quite consistent and that women tend to take into account their partner's workload: If the partner works long hours, it is more likely that they are childless and that they postpone fertility, while, if he works part time, it is more likely that they postpone fertility. Even if the significance levels do not reach, in all cases, the conventional levels of acceptance, the estimators point in that direction.

Summarising, it can be said that, besides age, childlessness among mobile women living in a partnership is conditioned mainly by the time they invest in paid work and employers' policies for balancing working and family lives. The postponement of having children, after controlling by the number of children, is not so clearly influenced by the working conditions, but a family-friendly policy in the workplace facilitates the realisation of maternity aspirations.

\section{Conclusion}

In the context of the family planning norm prevailing in developed societies, working conditions have emerged as one of the relevant circumstances that people take into account when pondering having children and deciding on the number of children they will have. Demographic literature on the topic has focused mainly on analysing the impact of work stability and flexibility of the labour market on the timing and quantum of fertility, paying attention also to the role of the institutional framework introduced to facilitate balancing working and family lives. This article has focused on the effects that high job mobility have on timing and quantum of parenthood of people with partnership experience, both men and women, as well as the possible impact of measures introduced by the employer to facilitate the balancing of mobility, work, and family have on the parenthood behaviour of mobile people living in a partnership.

The impact of high job mobility on the timing and quantum of parenthood is important, both for men and women, but stronger for the latter. Besides gender, the strength of the impact depends on the duration of job mobility and when it takes place in the lifecycle.

For men, job mobility implies an important postponement of the transition into fatherhood of about 2 years when mobility takes place before fathering a child, both for the first child as well as for a second child. When the parenthood decision was made before becoming job mobile, mobility, as could be expected, has no impact on the timing. The postponement of parenthood does not translate into a higher probability to be childless, so job mobile men have the same probability of being childless as never-mobiles and pastmobiles, but it can affect final family size. When high job mobility is not a more or less 
extended experience in the life course, but an enduring experience that began before deciding on parenthood and holds over the family building period, it tends to translate into a smaller family size. On the contrary, when job mobility becomes part of the working conditions after the transition into fatherhood, it does not appear to be at the cost of a smaller family size. Mobile men as a whole, however, do not have a smaller family size than never-mobiles, as is the case also with past-mobiles. The impact of mobility presents the same patterns for all educational levels, so highly educated men are neither more nor less affected by postponement and reduction of family size as less-educated men.

For women, who are much less involved in job mobility than men, job mobility has a much greater impact in their family life project than for men. The fact that mobility experiences decrease sharply with age among women but not among men suggests that there is a self-selection process whereby many women give up mobility during their reproductive period in order to accomplish their family life project. Mobility implies, for women, a higher risk of remaining childless; in fact, childlessness among mobile women whose reproductive period has ended is 2.5 higher than among never-mobiles and 1.7 higher than among men. Mobility implies also a postponement of the transition into motherhood when mobility occurs prior to the parenthood decision of about 2.4 years for the first child and 3.2 for the second, much more than among men, but not when mobility becomes a working condition after the transition into motherhood. When mobility is an enduring process over the reproductive period, it also translates into a smaller family size. Unlike for men, the family life project of women with higher levels of education are much more affected by mobility than those with no university degree, as they remain much more often childless and have fewer children.

The subjective evaluation of the impact of career on their family projects and their statements about their parenthood decisions confirm the results obtained analysing the timing and quantum of parenthood, both for women and men.

Mobility can take different forms. We have distinguished four broad types: Longdistance commuting, Overnighting, Relocation and Multi-mobility. None of these mobility types is irrelevant for family development, but none appears to be particularly family friendly. As stated before, its impact depends on the duration and timing, as well as on gender. For men, no mobility type has a greater or lesser impact on their family life projects for none of the analysed dimensions. For women, on the contrary, LDC appears as the one with the smallest impact in terms of childlessness and family size.

The impact of mobility on family development is conditioned not only by gender, age and when mobility occurs in the lifecycle, but also by the resources at hand for balancing working and mobility lives. As working conditions and availability of this kind of resources change over time, we have analysed its impact on the subjective perceptions of being childless and postponing having children for job-related reasons.

The results show that, for men, the time invested in paid work and in mobility does not appear to be relevant for their family development. Mobility implies a postponement in parenthood decisions, but the form it takes is not relevant. Active involvement of men in housework, on the contrary, deters them from having children and induces postponement of the decision. Greater time availability of the partner for family life has the opposite effect. The working conditions of the partner are much more relevant, as the amount of time invested in paid work and the mobility requirements of the partner are strongly 
related to childlessness, but not so clearly to postponement. This can be due to the lack of enough cases where both partners are mobile because men whose partner is job mobile are much more often childless and are postponing parenthood decisions (columns 4 to 6 in Table 8). Measures that usually are associated with promoting a better balance between working and family lives, such as flexitime and teleworking, do not seem to facilitate the transition into parenthood. However, a supporting employer seems to facilitate this transition, but not so strongly as could be expected, which does not mean that it is irrelevant for other dimensions of family life.

For women, on the contrary, the time they invest in paid work has much more impact on their family development than among men, and it appears as one the most relevant dimensions when mobile women decide on motherhood. Active involvement of the partner does not appear to facilitate their decisions as do neither flexitime nor teleworking. However, having a supportive employer facilitates the realisation of maternity aspirations.

\section{References}

Adsera, A. (2004). Changing fertility rates in developed countries. The impact of labor market conditions. Journal of Population Economics, 17, (1), pp. 17-43.

Ahn, N. \& Mira, P. (2002). A note on the changing relationship between fertility and female employment rates in developed countries. Journal of Population Economics, 15 (4), pp. 667-682.

Baizán, P. \& Martin García, T. (2007). Endogeneity and joint determinants of educational enrolment and first birth timing in France and West Germany. GENUS, LXII (2), pp. 89-117.

Bernardi, L., Klärner, A. \& von der Lippe, H. (2008). Job insecurity and the timing of parenthood: A comparison between Eastern and Western Germany. European Journal of Population, 24, (3), pp. 287-313.

Billari, F. \& Philipov, D. (2004). Education and the transition to motherhood: a comparative analysis of Western Europe. European Demographic Research Papers, 3, pp. 1-40.

Blossfeld H.-P. \& Huinink J. (1991). Human capital investments or norms of role transition? How women's schooling and career affect the process of family formation. American Journal of Sociology, 97 (1), pp. 143-168.

Bonnet, E. \& Orain, R. (2010). Job Careers and Job Mobility. In: N. F. Schneider \& B. Collet (Ed.), Mobile living across Europe. Volume II. Causes and consequences of job-related spatial mobility in cross-national perspective. Opladen \& Farmington Hills, MI: Barbara Budrich, pp. 289-315.

Brewster, K. L., \& Rindfuss, R. R. (2000). Fertility and women's employment in industralised nations. Annual Review of Sociology, 26, pp. 271-296.

Ekert-Jaffé, O., Hoshi, H., Lynch, K., Mougin, K. \& Rendal, M. (2002). Fertility, timing of births and socio-economic status in France and Britain: Social policies and occupational polarization. Population, English version, 57 (3), pp. 475-507.

Green, A. E. \& Canny, A. (2003). Geographical mobility. Family impacts. Bristol: Policy Press.

Hoem, B. (2000). Entry into motherhood in Sweden: The influence of economic factors on the rise and fall in fertility, 1986-1997. Demographic Research, 2 (4), article 4.

Huynen, Ph., Montulet, B., Hubert, M., Lück, D. \& Orain, R. (2008). Survey Design and Methods. In: N. F. Schneider \& G. Meil (Eds), Mobile living across Europe. Volume I. Relevance and diversity of job-related spatial mobility in six European countries. Opladen \& Farmington Hills, MI: Barbara Budrich, pp. 47-63.

Huynen, Ph., Hubert, M. \& Lück, D. (2010). Research design. In: N. F. Schneider \& B. Collet (Eds), Mobile living across Europe. Volume II. Causes and consequences of job-related spatial mobility in cross-national perspective. Opladen \& Farmington, MI: Barbara Budrich, pp. 23-34.

Kohler, H. P., Billari, F. C., \& Ortega, J. A. (2002). The emergence of lowest-low fertility in Europe during the 1990s. Population and Development Review, 28, (4), pp. 641-681. 
Kravdal, O. \& Rindfuss, R. (2008). Changing relationships between education and fertility: A study of women and men born 1940 to 1964. American Sociological Review, 73. (5), pp. 854-73.

Lesthaeghe, R. (1983). A century of demographic and cultural change in Western Europe: An exploration of underlying dimensions. Population and Development Review, 9 (3), pp. 411-435.

Limmer, R. (2005). Berufsmobilität und Familie in Deutschland. Zeitschrift für Familienforschung, 17, (2), pp. 96-114.

Meil, G.; Ayuso, L. \& Mahía, R. (2010). Support for job-mobile people and their adaptation to Mobility. In: N. F. Schneider \& B. Collet (Eds), Mobile living across Europe. Volume II. Causes and consequences of job-related spatial mobility in cross-national perspective. Opladen \& Farmington, MI: Barbara Budrich, pp. 317-336.

Meil, G. (2010), The effects of job mobilities on family life. In: N. F. Schneider \& B. Collet (Eds), Mobile living across Europe. Volume II. Causes and consequences of job-related spatial mobility in cross-national perspective. Opladen \& Farmington, MI: Barbara Budrich, pp. 215-235.

Meil, G., García Sainz, C., Luque, M. A., Ayuso, L. (2007). El desafio de la conciliación de la vida privada y laboral en las grandes empresas. Madrid: Fundación de la UAM.

Meil, G. (2006). Relaciones padres - hijos en la España de hoy. Barcelona: Fundación La Caixa, Colección de estudios sociales $\mathrm{n}^{\circ} 19$.

Meron, M. \& Wimer, I. (2002). Unemployment leads women to postpone the birth of their first child. Population, English version, 57, (2), pp. 301-330.

Nave-Herz, R. (2003). Ehe- und Familiensoziologie. Weinheim: Juventa.

Parent-Thirion, A., Fernández Macías, E., Hurley, J. \& Vermeylen, G. (2007). Fourth European Working Conditions Survey. Dublin: Eurofound.

Riedmann, A., Bielenski, H., Szczurowska, T. \& Wagner, A. (2006). Working time and work-life balance in European companies. Dublin: Eurofound.

Rossi, G. (Ed.) (2006). Reconciling family and work: New challenges for social policies in Europe. Milano: Franco Angeli.

Schneider, N., Limmer, R. \& Ruckdeschel, K. (2002). Mobil, flexibel, gebunden. Familie und Beruf in der mobilen Gesellschaft. Frankfurt am Main: Campus.

Schneider, N. \& Meil, G. (2008). Mobile living across Europe. Volume I. Relevance and diversity of jobrelated spatial mobility in six European countries. Opladen \& Farmington Hills, MI: Barbara Budrich Publishers.

Van de Kaa, D. J. (1987). Europe's second demographic transition. Population Bulletin, 42(1), pp. 1-57.

Submitted on/Eingereicht am: 26.04.2010

Accepted on/Angenommen am: 08.07.2010

Address of the author/Anschrift des Autors:

Prof. Dr. Gerardo Meil

Universidad Autónoma de Madrid

Facultad de Ciencias Económicas y Empresariales

Departamento de Sociología

c. Francisco Tomás y Valiente 5

Campus de Cantoblanco

28049 Madrid

Spain/Spanien

E-mail: gerardo.meil@uam.es 